\title{
Sistem Pendukung Keputusan Kelompok Pemilihan E-Commerrce Menggunakan Metode Profile Matching dan BORDA
}

\author{
Indra Pratistha*1 ${ }^{*}$, I.P.Agung Mahadewa ${ }^{2}$, Putu Sugiartawan ${ }^{3}$ \\ ${ }^{1,3}$ Fakultas MIPA, Ilmu Komputer dan Elektronika, Universitas Gadjah Mada, Yogyakarta \\ ${ }^{2}$ Fakultas Ekonomika dan Bisnis, Megister Manajemen, Universitas Gadjah Mada, Yogyakarta \\ e-mail: *11indra.pratistha@mail.ugm.ac.id, ${ }^{2}$ i.pt.a@mail.ugm.ac.id, \\ $\underline{3}$ Putu.sugiartawan@mail.ugm.ac.id
}

\begin{abstract}
Meningkatnya perkembangan teknologi informasi, membawa perkembangan terhadap pola kehidupan masyarakat Indonesia, khususnya pola konsumsi dan pengiriman barang. Masyarakat indonesia sangat dipermudah dan dimanjakan dalam mendapatkan barang dan jasa yang diinginkan. Perkembangan ini disebabkan dari merebaknya situs penyedian belanja online di indonesia, yang dapat diakases melalui smartphone dan komputer. Indonesia memiliki jumlah pengguna smart phone yang sangat tinggi, jika dilihat dari jumlah unique audiens pada akhir triwulan dua yang datanya diperoleh dari MMX Multi-platform, juni 2017. Salah satu model yang digunakan pada penelitian ini adalah metode Profile Matching, Metode tersebut dapat mengatasi permasalahan perankingan melalui pemberian bobot berdasarkan pencocokan dua profile yang diteliti pada kriteria masing-masing handphone. Kriteria yang didapat oleh pengguna akan menjadi nilai profile yang kemudian dicocokan dengan profile kesesuaian yang diberikan oleh DM. Penelitian ini menggunakan tiga buah penentu keputusan, diantaranya pakar ekonomi, pakar IT dan masyarakat. Untuk menggabungkan ketiga keputusan tersebut digunakan pendekatan metode BORDA. Metode BORDA merupakan metode voting yang dapat menyelesaikan pengambilan keputusan kelompok, dimana dalam penerapannya masing-masing decision maker (DM) memberikan peringkat berdasarkan alternatif pilihan yang ada. Selanjutnya penelitian ini akan menggunakan pendekatana metode profile matching dan BORDA dalam memilih marketplace terbaik. Hasil penelitian menunjukan market place shopie menempati peringkat pertama.
\end{abstract}

Kata kunci-Borda, DSS, decision maker, profile matching, GDSSS

Abstract

The increasing development of information technology, brings developments to the pattern of life of the Indonesian people, especially the pattern of consumption and shipping of goods. Indonesian society is greatly facilitated and spoiled in getting the desired goods and services. This development was caused by the spread of online shopping providers in Indonesia, which can be accessed via smartphones and computers. Indonesia has a very high number of smartphone users, judging from the number of unique audiences at the end of the second quarter, the data obtained from MMX Multi-platform, June 2017. One of the models used in this study is the Profile Matching method, the method can overcome problems ranking by giving weights based on matching two profiles examined on the criteria of each cell phone. The criteria obtained by the user will be the profile value which is then matched with the conformity profile provided by DM. This study uses three decision makers, including economists, IT experts, and the public. To combine the three decisions used the BORDA method approach. The

Received September $28^{\text {th }}, 2018$; Revised September 29 ${ }^{\text {th }}, 2018$; Accepted September $30^{\text {th }}, 2018$ 
BORDA method is a voting method that can resolve group decision making, wherein its application each decision maker (DM) provides a rating based on the alternative choices available. Furthermore, this research will use the approach of profile matching and BORDA methods in choosing the best marketplace. The results showed that Sophie's marketplace was ranked first.

Keywords - Borda, DSS, decision maker, profile matching, GDSSS

\section{PENDAHULUAN}

Era digital yang ditandai dengan meningkatnya perkembangan di dunia teknologi informasi, membawa perkembangan terhadap pola kehidupan masyarakat Indonesia, khususnya pola konsumsi dan pengiriman barang. Masyarakat indonesia sangat dipermudah dan dimanjakan dalam mendapatkan barang dan jasa yang diinginkan. Perkembangan ini disebabkan dari merebaknya situs penyedian belanja online di indonesia, yang dapat diakases melalui smartphone dan komputer. Perkembangan yang pesat pada belanja online membuat berbagai situs penyedia belanja online mulai bermunculan dan menyajikan berbagai alternative dan tawaran diskon bagi para pelanggan.

Indonesia memiliki jumlah pengguna smart phone yang sangat tinggi, jika dilihat dari jumlah unique audiens pada akhir triwulan dua yang datanya diperoleh dari MMX Multi-platform, juni 2017. Data dari 10 peringkat teratas yang terdiri atas 4 e-commerce dan 6 marketplace. Lazada memimpin seluruh e-commerce dengan 21,2 juta unique audiens. Sedangkan, Tokopedia memimpin marketplace dengan 14,4 juta. Urutan ke-10 peringkat teratas tersebut antara lain Lazada, Blibli, Tokopedia, Elevania, Matahari Mall, Shopee, Bukalapak, Zalora, Qoo10, dan Blanja. Namun fasilitas dan service yang ditawarkan masing-masing e-commerce berbeda antara satu dengan yang lainnnya, maka dari itu diperlukan sebuah perankingan kualitas, layanan dan fasilitas terbaik yang dimiliki oleh masing-masing marketplace. Adapun cara yang dilakukan untuk mendapatkan perankingan dan menentukan market place terbaik, dapat menggunakan pendekatan group decsision support system (GDSS). Penggunaan GDSS memungkinkan dapat menggabungkan keputusan para pakar yang memiliki persepsi berbedabeda terhadap marketplace.

Salah satu model yang digunakan pada penelitian ini adalah metode Profile Matching, Metode tersebut dapat mengatasi permasalahan perankingan melalui pemberian bobot berdasarkan pencocokan dua profile yang diteliti pada kriteria masing-masing handphone. Profile Matching atau pencocokan profil adalah metode yang sering digunakan sebagai mekanisme dalam pengambilan keputusan dengan mengamsusikan bahwa terdapat tingkat variabel prediktor yang ideal yang harus dipenuhi oleh subjek yang diteliti, bukan tingkat minimal yang harus dipenuhi atau dilewati [1]. Kriteria yang didapat oleh pengguna akan menjadi nilai profile yang kemudian dicocokan dengan profile kesesuaian yang diberikan oleh DM. Alternatif perankingan dihasilkan dari perhitungan nilai bobot yang didapat berdasarkan dari nilai kedekatan pada kelas kesesuaian dan fungsi interpolasi linier. Jika bobot yang dihasilkan semakin mendekati kelas kesesuain yang diharapkan maka semakin besar peluang alternatif dipilih menjadi market place terbaik.

Pada penelitian ini menggunakan tiga buah penentu keputusan, diantaranya pakar ekonomi, pakar IT dan masyarakat. Untuk menggabungkan ketiga keputusan tersebut digunakan pendekatan metode BORDA. Metode BORDA merupakan metode voting yang dapat menyelesaikan pengambilan keputusan kelompok, dimana dalam penerapannya masing-masing decision maker (DM) memberikan peringkat berdasarkan alternatif pilihan yang ada [2]. Selanjutnya penelitian ini akan menggunakan pendekatana metode profile matching dan BORDA dalam memilih marketplace terbaik. Adapun kreteria yang digunakan berjumlah 14

JSIKTI Vol. 1, No. 1, September 2018: $13-24$ 
kreteria, yang diantaranya harga, pengemasan, bonus, pengiriman, garansi dan lain-lain. Untuk alternatif terdiri dari lima yang diantaranya marketplace tokopedia, shopie, lazada, bukalapak dan Bhineka. Pemilihan alternatif berdasarkan dari banyaknya pengunjung yang mengunjungi marketplace.

\section{METODE PENELITIAN}

\section{1. State of the art}

Dasar-dasar penelitian sebelumnya yang menjadi rujukan pada penelitian ini diantaranya, Berbagai penerapan yang dapat dilakukan dengan melalui pendekatan model ANP dan Profile Matching sebagai contoh dalam rekomendasi pemilihan kandidat pejabat struktural menggunakan metode profile matching di lingkungan Pemerintahan Kota Tarakan yang sesuai dengan kemampuan bidang yang dibutuhkan dalam suatu jabatan melalui pencocokan antara profil calon dengan profil jabatan yang lowong [3]. Penelitian dengan model profile matching dan AHP dalam memberikan rekomendasi terhadap prioritas komoditas tanaman pangan untuk suatu lahan dengan mengolah data text dalam melakukan scoring untuk menentukan bobotbobot kriteria dan sup kriteria yang akan digunakan pada perhitungan nilai akhir pada metode AHP. Semakin kecil gap yang dihasilkan maka bobot nilainya semakin besar yang berarti peluang tanaman tersebut ditanam dilahan tersebut semakin besar [4]. Penelitian yang dilakukan untuk mengetahui kesesuaian lahan perkebunan kopi di Kabupaten Semarang dengan menggunakan metode AHP dan profil matching, tujuan dari penelitian ini untuk menentukan dan memetakan lokasi kesesuaian lahan, serta untuk mengetahui perbedaan penggunaan metode AHP dan metode profil matching. Penelitian dengan menerapkan metode profile matching dan pendekatan manajemen sumber daya manusia berbasis kompetensi terhadap penempatan karyawan dengan sistem pendukung keputusan, penelitian menggunakan 4 tahapan dalam perhitungan dengan metode profil matching yaitu pemetaan nilai GAP kompetensi, penentuan core \& secondary factor [5]. menghitung nilai total dan terakhir perankingan. Pengembangan DSS guna evaluasi kinerja karyawan terhadap penyederhanaan proses pengembangan meliputi 4 tahapan yaitu inisiasi sistem, analisis sistem, perancangan sistem dan implementasi sistem. Hasil yang diperoleh didapatkannya informasi gap antara kompetensi karyawan dengan ekspektasi perusahaan [5].

\subsection{Sistem Pendukung Keputusan}

Menyatakan bahwa sistem pendukung keputusan merupakan sistem penghasil informasi yang ditunjukan pada suatu masalah yang harus dibuat oleh manajer, sistem pendukung keputusan merupakan suatu sistem informasi yang ditujukan untuk membantu manajemen dalam memecahkan masalah yang dihadapinya [6].

Sistem Pendukung Keputusan (Decision Support System) adalah sistem berbasis komputer yang interaktif dalam membantu pengambil keputusan dengan memanfaatkan data dan model untuk menyelesaikan masalah-masalah yang tak terstruktur [6]. Tujuan Sistem Pendukung Keputusan ini terdiri dari tiga tujuan yang akan dicapai yaitu [6]:

1. Membantu Manajer membuat keputusan untuk memecahkan masalah semi terstruktur.

2. Mendukung penilaian manajer bukan mencoba menggantikannya.

3. Meningkatkan efektifitas pengambilan keputusan manajer daripada efesiensinya.

Karakteristik dan Kemampuan Sistem Pendukung Keputusan

Pada Gambar 1 menunjukan karakteristik dan kemampuan sebuah sistem pendukung keputusan [6]. Karakteristik dan kemampuan sebuah sistem pendukung keputusan dapat dijelaskan sebagai berikut:

1. Sistem pendukung keputusan menyediakan dukungan untuk pengambil keputusan utamanya pada keadaan-keadaan semi terstruktur dan tidak terstruktur dengan menggabungkan penilaian manusia dan informasi komputerisasi.

2. Menyediakan dukungan untuk tingkat manajerial mulai dari eksekutif sampai manajer. 
3. Menyediakan dukungan untuk kelompok individu, problem-problem yang kurang terstruktur memerlukan keterlibatan beberapa individu dari departemen-departemen yang lain dalam organisasi.

4. Sistem pendukung keputusan menyediakan dukungan kepada independen atau keputusan yang berlanjut.

5. Sistem pendukung keputusan memberikan dukungan kepada semua fase dalam proses pembuatan keputusan intelligence, design, choice dan implementation.

6. Sistem pendukung keputusan mendukung banyak proses dan gaya pengambil keputusan.

7. Sistem pendukung keputusan bersifat adaptive adaptive terhadap waktu, sehingga pembuat keputusan harus reaktif dan bisa menghadapi perubahan-perubahan kondisi secara cepat dan merubah sistem pendukung keputusan menjadi fleksibel sehingga pengguna dapat menambah, menghapus, mengkombinasikan, merubah dan mengatur kembali terhadap elemen-elemen dasar.

8. Sistem pendukung keputusan mudah digunakan. Pengguna merasa nyaman, seperti userfriendly, fleksibel. Kemampuan penggunaan grafik yang tinggi dan bahasa yang mudah dipahami untuk berinteraksi dengan mesin akan memberikan efektivitas dari sistem pendukung keputusan.

9. Sistem pendukung keputusan menaikkan efektivitas pembuatan keputusan baik dalam hal ketepatan waktu dan kualitas bukan pada biaya pembuatan keputusan atau biaya penggunaan waktu komputer.

10. Pembuat keputusan dapat mengontrol tahapan-tahapan pembuatan keputusan seperti pada tahap intelligence, choice dan implementation kemudian sistem pendukung keputusan diarahkan untuk mendukung si pembuat keputusan bukan menggantikan posisinya.

11. Memungkinkan pengguna akhir dapat membangun sistem sendiri yang sederhana. Sistem yang besar dapat dibangun dengan bantuan dari spesialis sistem informasi.

12. Sistem pendukungkeputusan menggunakan model-model standar atau buatan pengguna untuk menganalisa keadaan-keadaan keputusan. Kemampuan modelling memungkinkan sistem bereksperimen ddengan strategi yang berbeda-beda dibawah konfigurasi yang berbeda-beda pula.

13. Sistem pendukung keputusan mendukung akses dari bermacam-macam sumber data, format, dan tipe serta jangkauan dari sistem informasi geografi pada orientasi objek.

14. Sistem pendukung keputusan mengarah pada pembelajaran bahkan SPK dalam tingkat lanjut dilengkapi dengan komponen knowledge yang bisa memberikan solusi yang efesien dan efektiv dari berbagai masalah yang rumit.

\section{2 Interpolasi linier}

Interpolasi linier merupakan salah satu metode yang paling sederhana untuk menemukan suatu nilai dalam suatu grafik yang memiliki 2 buah titik yang terhubung secara garis lurus. Bentuk linier dibuat dengan cara menarik garis lurus diantara dua titik temu yang diketahui, yaitu A dan E. Selanjutnya, dengan menarik garis data yang diketahui yaitu xi dan $f(x i)$, maka hubungan dua segitiga, yaitu segitiga sebangun ABC dan ADE, dimana terdapat hubungan yang dapat dilihat pada persamaan 1 adalah sebagai berikut:

$$
\frac{B C}{A B}=\frac{D E}{A D}
$$

Berikut adalah gambar 2 bentuk grafik dari interpolasi linier

Dari persamaan 2 dapat dibentuk persamaan baru, maka diperoleh persamaan 2 sebagai berikut:

$$
\frac{f(x)-f\left(x_{0}\right)}{x-x_{0}}=\frac{f\left(x_{i}\right)-f\left(x_{0}\right)}{x_{i}-x_{0}}
$$

Untuk mendapatkan nilai $f(x)$ dari persamaan 2, maka diperoleh persamaan 3 sebagai berikut:

$$
f(x)=f\left(x_{0}\right)+\frac{f\left(x_{i}\right)-f\left(x_{0}\right)}{x_{i}-x_{0}}\left(f\left(x_{i}\right)-f\left(x_{0}\right)\right)
$$

JSIKTI Vol. 1, No. 1, September 2018: $13-24$ 


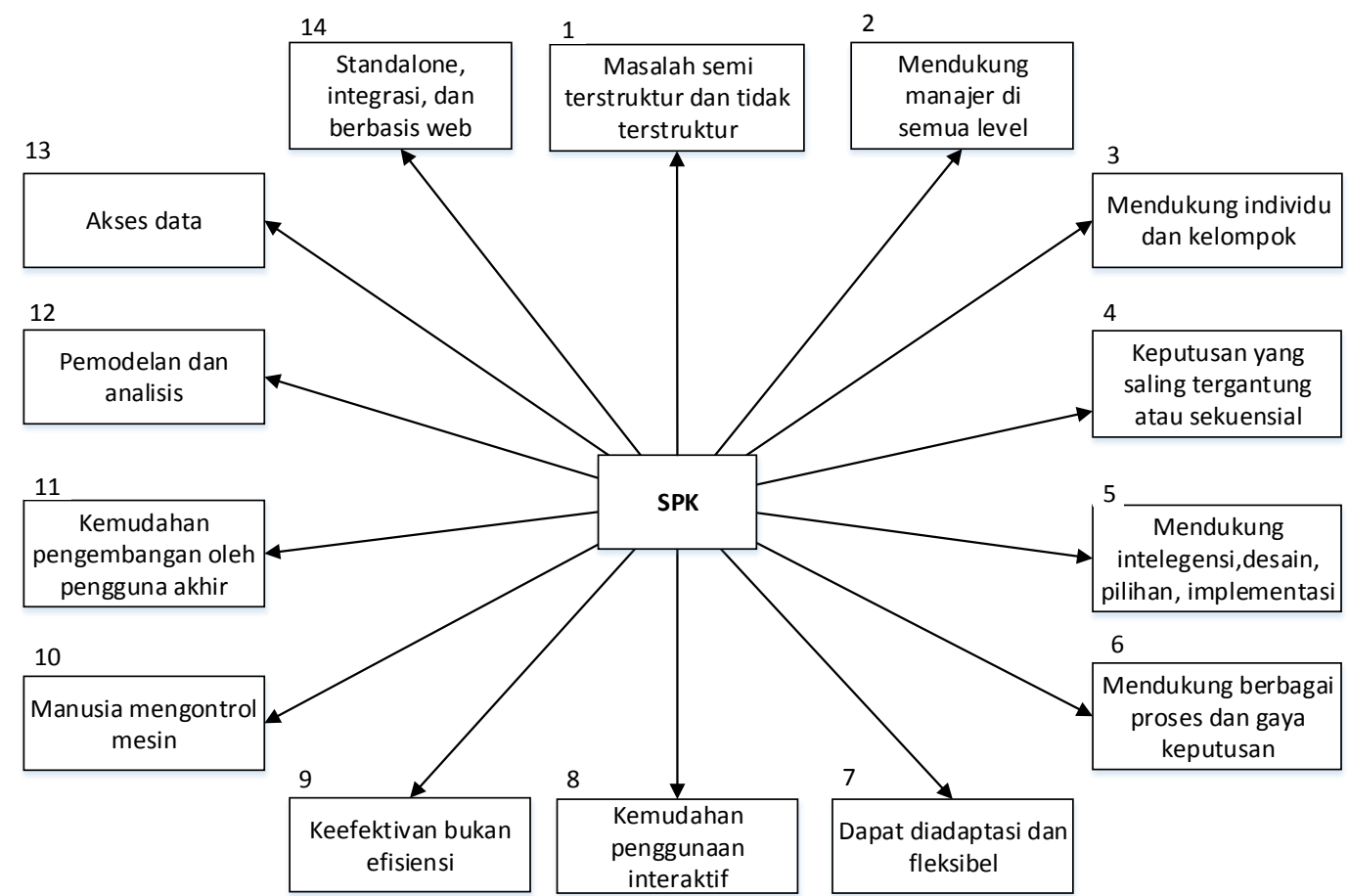

Gambar 1 Karakteristik dan Kapabilitas SPK [7]

Dari persamaan 3 dapat diubah menjadi bentuk persamaan 4

$$
f(x)=f\left(x_{0}\right)+\frac{f\left(x_{i}\right)-f\left[x_{0} y\right.}{x_{1}-x_{0}}\left(x-x_{0}\right)
$$

$f(x) \quad$ : nilai pada sumbu $\mathrm{Y}$ terhadap nilai $x$ pada sumbu $\mathrm{X}$ yang dicari.

$f\left(x_{0}\right) \quad$ : nilai pada sumbu Y terhadap nilai $x_{0}$ pada sumbu X posisi titik sebelah kiri

$f\left(x_{i}\right) \quad$ : nilai pada sumbu Y terhadap nilai $x_{i}$ pada sumbu X posisi titik sebelah kanan

$\mathrm{x}_{0} \quad$ : posisi titik sebelah kiri pada sumbu $\mathrm{X}$.

$\mathrm{x}_{\mathrm{i}} \quad$ : posisi titik sebelah kanan pada sumbu $\mathrm{X}$.

$\mathrm{X}$ : posisi titik yang dicari pada sumbu $\mathrm{X}$.

\section{3 Profile Matching}

Metode Profile Matching atau pencocokan profil adalah metode yang sering digunakan sebagai mekanisme dalam pengambilan keputusan dengan mengamsusikan bahwa terdapat tingkat variabel prediktor yang ideal yang harus dipenuhi oleh subjek yang diteliti, bukan tingkat minimal yang harus dipenuhi atau dilewati [3]. Secara garis besar, Profile Matching merupakan proses membandingkan antara nilai data aktual dari suatu profil yang akan dinilai dengan nilai profil yang diharapkan, sehingga dapat diketahui perbedaan kompetensinya (disebut juga gap). Semakin kecil gap yang dihasilkan maka bobot nilainya semakin besar.

Berikut adalah beberapa tahapan dan perumusan perhitungan dengan metode profile matching:

1. Pemetaan nilai gap

Melakukan pemetaan gap kompetensi, gap yang dimaksud adalah perbedaan antara profil atribut dengan profil target. Untuk mendapat nilai selisih atau gap dari kedua profil tersebut, dapat menggunakan persamaan 5 .

$$
\text { Gap }=\text { Value Atribut }- \text { Value Target }
$$




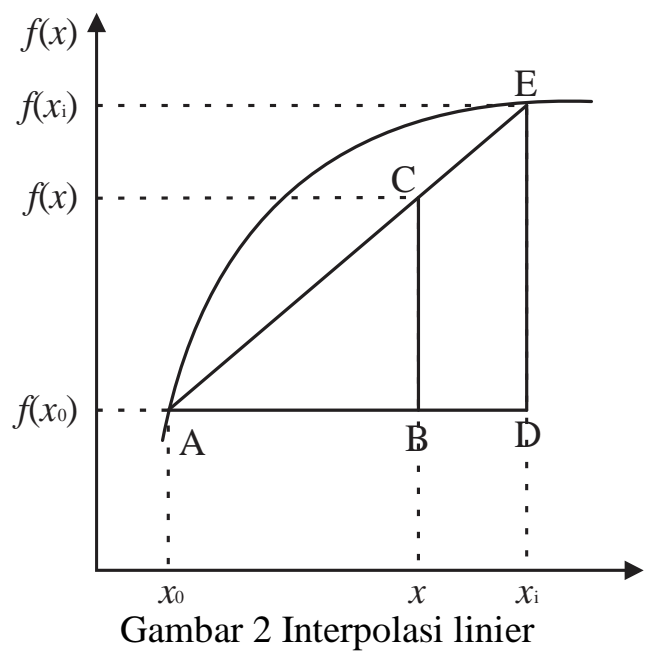

2. Pembobotan.

Penentuan bobot nilai gap kompetensi. Pada tahap ini akan ditentukan bobot nilai dari masing-masing nilai gap dengan mengacu pada Tabel 1 bobot nilai GAP.

Tabel 1 Bobot nilai GAP

\begin{tabular}{|l|c|c|l|}
\hline No. & $\begin{array}{c}\text { Selisih } \\
\text { GAP }\end{array}$ & $\begin{array}{c}\text { Bobot } \\
\text { Nilai }\end{array}$ & \multicolumn{1}{c|}{ Keterangan } \\
\hline 1. & 0 & 5 & Kompetensi sesuai dengan yang dibutuhkan \\
\hline 2. & 1 & 4.5 & Kompetensi individu kelebihan 1 tingkat / level \\
\hline 3. & -1 & 4. & Kompetensi individu kurang 1 tingkat / level \\
\hline 4. & 2 & 3.5 & Kompetensi individu kelebihan 2 tingkat / level \\
\hline 5. & -2 & 3 & Kompetensi individu kurang 2 tingkat / level \\
\hline 6. & 3 & 2.5 & Kompetensi individu kelebihan 3 tingkat / level \\
\hline 7. & -3 & 2 & Kompetensi individu kurang 3 tingkat / level \\
\hline 8. & 4 & 1.5 & Kompetensi individu kelebihan 4 tingkat / level \\
\hline 9. & -4 & 1 & Kompetensi individu kurang 4 tingkat / level \\
\hline
\end{tabular}

3. Core dan Secondary Factor.

Dimana pada tahap ini akan dilakukan penentuan nilai dari masing aspek core factor dan secondary factor. Core factor merupakan aspek (kompetensi) yang paling menonjol/paling dibutuhkan oleh suatu jabatan yang diperkirakan dapat menghasilkan kinerja optimal. Secondary factor adalah item-item selain aspek yang ada pada core factor.

4. Perhitungan nilai total, menghitung nilai total dari semua aspek berdasarkan nilai rata-rata core factor dan secondary factor yang telah dihasilkan dengan presentase dari masingmasing dactor yang diinputkan yaitu core factor diberikan nilai sebesar $60 \%$ dan secondary factor diberikan nilai sebesar 40\%, berikut adalah persamaan 6 yang digunakan untuk menghitung nilai total.

$$
N=(x) \% \cdot N C F+(x) \% \cdot N S F
$$

Keterangan:
$N \quad$ : Nilai total
$X \quad$ : Besarnya nilai persen
NCF : Nilai core factor
NSF : Nilai secondary factor 
5. Perankingan.Penentuan nilai rangking. Hasil akhir dari proses perhitungan model Profile Matching adalah menghitung nilai rangking jabatan-jabatan yang ditawarkan. Dimana menentukan rangking dapat menggunakan persamaan 7 .

Keterangan:

$$
\text { Rangking }=\left(\left(x_{1}\right) \cdot N_{1}\right)+\left(\left(x_{2}\right) \cdot N_{2}\right)+\cdots+\left(\left(x_{n}\right) \cdot N_{n}\right)
$$

$\begin{array}{ll}\mathrm{X} & \text { : Bobot yang dimasukkan tiap parameter. } \\ \mathrm{N}_{1} & \text { : Nilai akhir parameter ke-1 } \\ \mathrm{N}_{2} & \text { : Nilai akhir parameter ke-2 } \\ \mathrm{N}_{\mathrm{n}} & \text { : Nilai akhir parameter ke-n }\end{array}$

\section{3 BORDA}

Metode Borda merupakan metode voting yang dapat menyelesaikan pengambilan keputusan kelompok, dimana dalam penerapannya masing-masing decision maker (DM) memberikan peringkat berdasarkan alternatif pilihan yang ada, proses pemilihan dalam metode Borda, masing-masing voter diberikan alternatif pilihan [8][9]. Di misalkan ada $n$ kandidat pilihan, kandidat atau alternatif pertama diberikan $\mathrm{n}$ poin oleh voter atau decisian maker. Kandidat kedua diberikan poin n-1 dan seterusnnya. Penentuan pemenang atau alternatif terbaik berdasarkan poin yang tertinggi. Alternatif dengan nilai tertinggi merupakan bahan pertimbangan yang akan dipilih [2].

Metode Borda juga dipakai pada pengambilan keputusan kelompok untuk pemilihan single winner ataupun multiple winner, dimana pemberi suara (voters) melakukan perangkingan terhadap kandidat yang disusun berdasarkan pilihan (preference)[2][10]. Borda menentukan pemenang dari suatu pemilihan dengan memberikan suatu jumlah point tertentu untuk masingmasing kandidat sesuai dengan posisi yang diatur oleh masing-masing pemberi suara.

Pemenang akan ditentukan oleh banyaknya jumlah point yang dikumpulkan atau di peroleh masing-masing kandidat. Borda sering digunakan pada suatu sistem pemilihan based consensus. Pemilihan dan perhitungan (voting and counting) dilakukan dengan cara memberikan sejumlah point kepada masing-masing calon (candidate) misalnya ada lima kandidat pada suatu pemilihan maka masing-masing calon menerima 5 point untuk kandidat ranking pertama, 4 point untuk kandidat rangking kedua dan seterusnya, kandidat terakhir menerima 1 point, dengan kata lain dimana $\mathrm{n}$ kandidat akan menerima $\mathrm{n}$ point untuk pilihan pertama, n-1 untuk pilihan kedua, n-2 untuk pilihan 3, n-4 untuk pilihan 5

Perhitungan Metode Borda

1. Diketahui ada 3 alternatif yang akan dilakukan perangkingan (A,B dan C). Dilakukan penyebaran questioner untuk mengetahu data dasar yang akan dijadikan perangkingan.

2. Dari hasil kuisioner, hitung jumlah responden yang menyatakan ranking untuk tiap jenis. Misalnya terdapat 4 responden yang menyatakan jenis A berada di peringkat 2 dan 3 responden menyatakan jenis berada di peringkat 3, maka tuliskan angka 4 pada kolom jenis A peringkat 2 dan angka 3 pada kolom jenis A peringkat 3 . Hal yang sama dilakukan untuk jenis yang lain.

3. Kalikan angka pada kolom peringkat dengan bobot di bawahnya, kemudian tambahkan dengan hasil perkalian pada jenis yang sama, kemudian isikan hasilnya pada kolom ranking. Misalnya untuk jenis A, $(0 \times 2)+(4 \times 1)+(3 \times 0)=4$.

4. Jumlahkan hasil ranking, yang dalam contoh ini berarti: $4+11+5=20$.

5. Untuk mencari bobot tiap jenis, bagi ranking dengan jumlah ranking. Jenis $A=4 / 20=0.2$, dan seterusnya.

6. Jenis dengan bobot tertinggi merupakan yang terpilih. 
Adapun metodologi pada penelitian ini ditunjukan pada Gambar 3, dimana terdapat tiga penentu keputusan yang disimbolkan dengan DM. Ketiga 3 di jabarkan pada Tabel 2. Sedangkan terdapat lima buah alternatif yang di tunjukan pada Tabel 3 dan terdapat 14 kreteria yang di tunjukan pada Tabel 4. Pada penelitian ini proses penentu keputusan pemilihan market place terbagi menjadi beberapa tahapan, diantaranya ;

1. Penentuan alternatif beserta kreteria masing-masing DM

2. Penentuan nilai masing-masing kreteria dan menghitung bobot masing-masing alternatif pada setiap DM

3. Meranking secara individu alternatif untuk setiap DM

4. Perankingan secara kelompok untuk masing-masing ranking yang dihasilkan oleh DM

Tabel 2 Decision maker market place terbaik dan kriterianya

\begin{tabular}{|l|l|l|l|l|l|l|l|l|}
\hline \multicolumn{7}{|c|}{ DM } \\
\hline Kode & Keterangan & \multicolumn{7}{|c|}{ Kriteria } \\
\hline DM 1 & Ekonomi & K1 & K3 & K6 & K7 & K8 & K9 & K14 \\
\hline DM2 & Pengamat IT & K4 & K5 & K10 & K11 & K12 & & \\
\hline DM3 & Masyarakat & K2 & K3 & K11 & K13 & & & \\
\hline
\end{tabular}

Masing-masing market palace memiliki kreteria yang berbeda-beda tergantung dari DM, pada penelitian ini DM 1 terdiri dari pakar ekonomi, DM 2 terdiri dari pengamat IT dan DM 3 merupakan masyarakat yang sering mengunakan layanan ke 5 market place pada Tabel 4 .

Tabel 3 Kreteria market place

\begin{tabular}{|l|l|}
\hline \multicolumn{2}{|c|}{ Kriteria } \\
\hline Kode & \multicolumn{1}{|c|}{ parameter } \\
\hline K1 & Harga \\
\hline K2 & Rating Produk \\
\hline K3 & Pilihan Pengiriman \\
\hline K4 & Jumlah Toko \\
\hline K5 & Pemilihan Account \\
\hline K6 & Garansi Pengiriman \\
\hline K7 & Garansi Penjualan \\
\hline K8 & Garansi Toko Daring \\
\hline K9 & Pengemasan \\
\hline K10 & User Friendly \\
\hline K11 & Pilihan Pembayaran \\
\hline K12 & Keamanan Transaksi \\
\hline K13 & Komentar Pembeli \\
\hline K14 & Bonus \\
\hline
\end{tabular}

JSIKTI Vol. 1, No. 1, September 2018: $13-24$ 
Sedangkan Alternatif terdiri dari lima alternatif, pemilihan kelima alternatif pada Tabel 4 berdasarkan dari observasi market place terbesar dan terbanyak yang dikunjungi pembeli. Adapun kreteria masing-masing DM terhadap pemilihan market place dijabarkan padaTabel 3.

Tabel 4 Alternatif market place
\begin{tabular}{|l|l|}
\hline \multicolumn{2}{|c|}{ Alternatif } \\
\hline Kode & \multicolumn{1}{|c|}{ Parameter } \\
\hline A1 & Tokopedia \\
\hline A2 & Bukalapak \\
\hline A3 & Shopee \\
\hline A4 & Lazada \\
\hline A5 & Bhinneka \\
\hline
\end{tabular}

Gambar 3.

Rancangan desain untuk GDSS pemilihan market place terbaik, dijabarkan pada

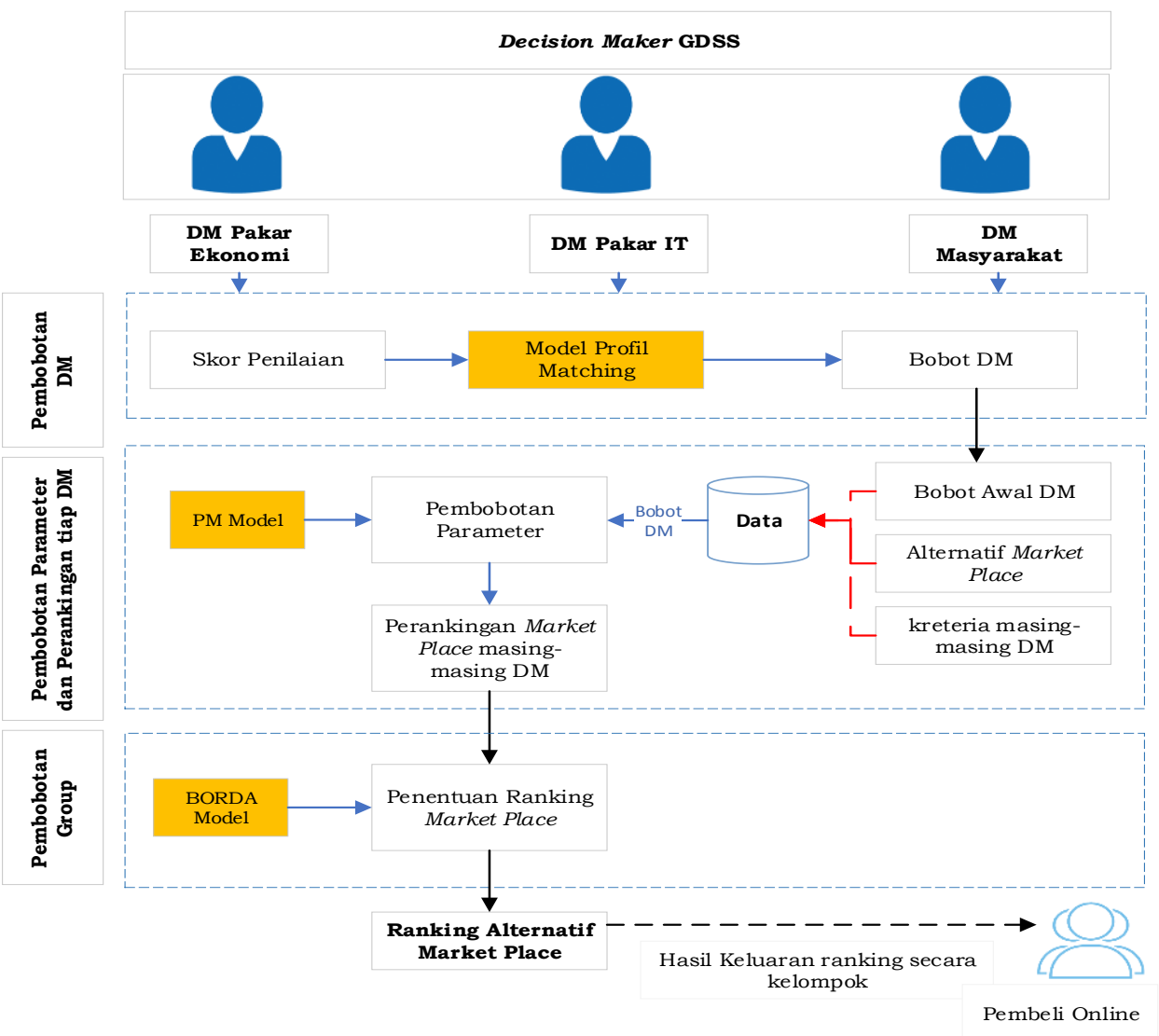

Gambar 3 Rancangan GDSS pemilihan market place 
Adapun proses pemilihan dilakukan dengan menggunakan metode profil matching untuk menentukan perankingan masing-masing DM dan selanjutnya menggabungkan hasil perankingan tersebut menjadi sebuah perankingan kelompok, yang terdiri dari pakar ekonomi, pengamat IT dan masyarakat.

\section{HASIL DAN PEMBAHASAN}

Hasil perhitungan dengan menggunakan metode profil matching, menghasilkan ranking Individu masing-masing DM, seperti yang ditunjukan pada Tabel 5. Hasil perankingan masingmasing DM berbeda satu dengan yang lainnya. Pada DM1 Pakar Ekonomi ranking pertama dihasilkan oleh market place Bukalapak, sedangkan ranking terakhir dihasilkan oleh market place Bhinneka. DM2 Pengamat IT menghasilkan ranking pertama ditempati oleh market place Shopee, sedangkan ranking terakhir dihasilkan oleh market place Bhinneka. DM Masyarakat ranking pertama dihasilkan oleh market place Shopee, sedangkan ranking terakhir dihasilkan oleh market place Bhinneka.

Tabel 4. Perbandingan Algoritma A dan Algoritma B

\begin{tabular}{|l|c|c|c|}
\hline \multirow{2}{*}{ Market Place } & \multicolumn{3}{|c|}{ Ranking } \\
\cline { 2 - 4 } & $\begin{array}{c}\text { DM 1 } \\
\text { Pakar Ekonomi }\end{array}$ & $\begin{array}{c}\text { DM 2 } \\
\text { Pakar IT }\end{array}$ & $\begin{array}{c}\text { DM 3 } \\
\text { Masyarakat }\end{array}$ \\
\hline Tokopedia & 11 & 10 & 8 \\
\hline Bukalapak & 12 & 10 & 9 \\
\hline Shopee & 11 & 11 & 11 \\
\hline Lazada & 10 & 8 & 7 \\
\hline Bhinneka & 9 & 8 & 6 \\
\hline
\end{tabular}

Adapun hasil perankingan secara kelompok dengan menggunakan metode BORDA, ditunjukan pada Tabel 5. Hasil perhitungan menunjukan market place Shopee menduduki peringkat pertama, market place Bukalapak menduduki peringkat kedua, market place Tokopedia menduduki peringkat ketiga, market place Lazada menduduki peringkat keempat dan peringkat terkhir ditempati oleh market place Bhinneka.

Tabel 5. Menentukan ranking

\begin{tabular}{|l|c|c|c|}
\hline \multirow{2}{*}{ Market Place } & \multicolumn{3}{|c|}{ Ranking } \\
\cline { 2 - 4 } & $\begin{array}{c}\text { DM 1 } \\
\text { Pakar Ekonomi }\end{array}$ & $\begin{array}{c}\text { DM 2 } \\
\text { Pakar IT }\end{array}$ & $\begin{array}{c}\text { DM 3 } \\
\text { Masyarakat }\end{array}$ \\
\hline Tokopedia & 2 & 2 & 3 \\
\hline Bukalapak & 1 & 3 & 2 \\
\hline Shopee & 3 & 1 & 1 \\
\hline Lazada & 4 & 4 & 4 \\
\hline Bhinneka & 5 & 5 & 5 \\
\hline
\end{tabular}

Tabel 7 menunjukan penilaian terhadap metode BORDA yang didapatkan melalui tabel penilaian khusus yang dapat dilihat pada Tabel 6 . Sehingga didapatkan

Tabel 6. Penilaian khusus

\begin{tabular}{|c|l|l|l|l|l|}
\hline Ranking & 1 & 2 & 3 & 4 & 5 \\
\hline Point & 5 & 4 & 3 & 2 & 1 \\
\hline
\end{tabular}


Tabel 7. Penilaian terhadap ranking metode BORDA

\begin{tabular}{|l|c|c|c|c|c|}
\hline \multirow{3}{*}{ Market Place } & \multicolumn{3}{|c|}{ Point BORDA } & \multirow{2}{*}{ Ranking } \\
\cline { 2 - 4 } & $\begin{array}{c}\text { DM 1 } \\
\text { Pakar Ekonomi }\end{array}$ & $\begin{array}{c}\text { DM 2 } \\
\text { Pakar IT }\end{array}$ & $\begin{array}{c}\text { DM 3 } \\
\text { Masyarakat }\end{array}$ & & Kelompok \\
\hline Tokopedia & 4 & 4 & 3 & 11 & 3 \\
\hline Bukalapak & 5 & 3 & 4 & 12 & 2 \\
\hline Shopee & 3 & 5 & 5 & 13 & 1 \\
\hline Lazada & 2 & 2 & 2 & 6 & 4 \\
\hline Bhinneka & 1 & 1 & 1 & 3 & 5 \\
\hline
\end{tabular}

\section{KESIMPULAN}

Kesimpulan yang dapat diambil dari penelitian ini adalah metode Profil Matching mampu mengindentifikasi peringkat market palce berdasarkan kreteria yang dimiliki oleh masing-masing DM, hasil penelitian menunjukan dari setiap memiliki pembobotan yang berbeda pada setiap kriteria, ini membuat hasil dari perankingan pada metode profil matching menjadi berbeda pada setiap DM sehingga pada DM1 ranking tertinggi ditempati oleh Bukalapak, pada DM2 ditempati Shopee dan pada DM3 ditempati oleh Shopee. Model BORDA dapat mengakomodasi keinginan seluruh DM dalam perankingan secara kelompok, yang diperoleh dari ranking masing-masing DM. Adapun hasil penelitian adalah sebagai berikut. Hasil penelitian menunjukan Market Place Shopee menduduki peringkat teratas melalui penentuan poin BORDA yang kemudian didtotalkan setiap barisnya terakhir diranking.

\section{SARAN}

Saran yang diperlukan dari penelitian ini adalah dengan menambah jumlah alternatif yang tersedia di Indonesia, beserta masing-masing kreteria yang ada. Diperlukan sebuah perbandingan dengan menggunakan model MADM lainnya, seperti AHP, ANP dan lainnya. Perlunya pembobotan untuk masing-masing DM, sehingga keputusan masing-masing DM tidak sama porsinya.

\section{DAFTAR PUSTAKA}

[1] Kusrini., 2007, Konsep Dan Aplikasi Sistem Pendukung Keputusan, Yogyakarta, Andi Offset

[2] Wang, C.W.C. and Leung, H.L.H., 2004, A Secure And Fully Private Borda Voting Protocol With Universal Verifiability, Proceedings of the 28th Annual International Computer Software and Applications Conference, IEEE Journal \& Magazines, 0730$3157 / 04$.

[3] Astriratma, R., Wardoyo, R. \& Musdholifah, A., 2017, SPK Rekomendasi Pemilihan Kandidat Pejabat Struktural Menggunakan Metode Profile Matching (Studi Kasus: Pemerintah Kota Tarakan), IJCCS, 11, 1, 77-88.

[4] Khairunnisa. \& Wardoyo, R., 2017, SPK Untuk Merekomendasikan Kesesuaian Lahan Pada Komoditas Tanaman Prioritas Dengan Profile Matching dan AHP, Jurnal Ilmiah Ilmu Komputer Universitas Udayana, 10, 2, 15-24. 
[5] Nasriyah, R., Arham, Z. \& Aini, Q., 2016, Profile Matching Ana Competency Based Human Resources Management Approaches for Employee Placement Decision Support System (Case Study), Aseian Journal of Pratiwi, H., 2016, Buku Ajar Sistem Pendukung Keputusan Ed.1, Cet.1, Yogyakarta, Deepublish, September 2016.

[6] Sasongko, S.B., 2010, Metode Numerik Dengan Scilab, Yogyakarta, Andi Offset.

[7] Turban, E., Aronson, J.E. and Liang, T.-P., 2005, Decision Support System And Intelligent Systems (diterjemahkan oleh Prabantini, D., Edisi 7, Andi, Yogyakarta.

[8] Claudio, D., Chen, J. and Okudan, G.E., 2008, AHP Based Borda Count : A Hybrid Multi-Person Decision Making Method for Design Concept Selection School of Engineering Design, IEEE Journal \& Magazines, pp.776-782.

[9] Purwantara, M., 2012, Sistem Pendukung Keputusan Kelompok Evaluasi Infrastruktur Jalan Raya Terhadap Kemacetan Lalu Lintas Menggunakan Metode Topsis Dan Borda, Tesis, Ilmu Komputer, Universitas Gadjah Mada.

[10] Wang, C.W.C. and Leung, H.L.H., 2004, A Secure And Fully Private Borda Voting Protocol With Universal Verifiability, Proceedings of the 28th Annual International Computer Software and Applications Conference, IEEE Journal \& Magazines, 0730$3157 / 04$. 